\title{
THE POTENTIAL OF HETEROTROPHIC MICROALGAE (Schizochytrium sp.) AS A SOURCE OF DHA
}

\section{Potensi Mikroalga Heterotroph (Schizochytrium sp.) sebagai Sumber DHA}

\author{
Arif Rahman Hakim \\ 1) Research Institute for Fisheries Post-harvest Mechanization; \\ *Correspondence author: Arif Rahman Hakim, KS. Tubun Petamburan VI Jakarta Pusat 10260, E-mail: arkola_05@yahoo.co.id
}

\begin{abstract}
Docosahexanoic acid (DHA) is commercially obtained from marine fish. With an increasing human population, the supplies of DHA are still not sufficient to meet the world's need of DHA as food supplement. The objective of this review is to discuss Schizochytrium sp., one of microalgae which is rich in DHA, as one of the best candidate as producer of sustainable and affordable DHA. Heterotrophic microalgae, especially genus Schizochytrium, produces omega-3 fatty acids up to $40 \%$ of total unsaturated fatty acids. Cultivation of the microalgae is easy as it does not require sunlight as source of energy. Previous publication reported that several local strains of Schizochytrium have been isolated from mangrove area in Indonesia. We expect that those strains can be cultivated in mass production as producer of DHA.
\end{abstract}

Keywords: docosahexanoic acids, fatty acids, Schizochytrium sp.

\section{ABSTRAK}

Docosahexanoic acid (DHA) komersial sebagian besar diperoleh dari ikan laut. Dengan meningkatnya populasi penduduk dunia, sumber ini tidak akan mencukupi permintaan dari masyarakat terhadap DHA sebagai salah satu makanan kesehatan. Tujuan dari review ini adalah untuk mendiskusikan Schizochytrium sebagai salah satu mikroalga yang kaya DHA, sebagai kandidat mikroalga yang mampu memproduksi DHA secara berkelanjutan dan terjangkau. Jenis mikroalga yang bersifat heterotrof terutama genus Schizochytrium mampu menghasilkan asam lemak omega 3 mencapai $40 \%$ dari total asam lemak tak jenuhnya. Kultivasi mikroalga ini juga lebih mudah karena tidak membutuhkan sinar matahari sebagai sumber energinya. Publikasi sebelumnya menunjukkan bahwa beberapa strain lokal telah di isolasi dari daerah mangrove di Indonesia. Kami berharap strain tersebut bisa dikembangkan ke produksi DHA secara masal.

Kata Kunci: asam docosaheksanoat, asam lemak, Schizochytrium sp.

\section{INTRODUCTION}

Docosahexanoic acid (DHA; 22:6(n-3)) and Eicosapentanoic acid (EPA ; $20: 5(\mathrm{n}-3)$ ) are long chain polyunsaturated fatty acids that is referred to omega 3. Both of these fatty acids have beneficial effect to the human body such as maintaining cardiovascular health, preventing or treating arteriosclerosis and certain cancer (Nettleton, 1995; Ward \& Singh, 2005).

Marine fish such as salmon, mackerel, and tuna are sources of omega-3. On the other hand, over fishing, pollution, and global climate change caused scarcity in the sustainability of omega 3 sources (Lewis et al., 1999). Moreover, the application of fish oil as food additive is limited due to problems associated with its smell characteristic, unpleasant taste, and poor oxidative stability (Spolaore et al., 2006). As consequence, various studies should be conducted continuously in order to find better quality and sustainable sources of omega-3 (De Swaaf et al., 2003).

Some marine microalgae such as dinoflagellates and species in the Heterokonta phylum contain high DHA (Barclay et al., 1994; Apt \& Behrens, 1999; De Swaaf et al., 2003; Wu \& Lin, 2003; Wu et al., 2005). However, majority of those microalgae are photoautotrophic that dependent on light as energy source and on weather conditions. Heterotrophic microalgae are able to take energy from simple organic substances without requiring light (Apt \& Behrens, 1999). One of heterotrophic microalgae is Schizochytrium sp. which can be utilized as an 
alternative to replace of fish oils due to its rapid growth rate; its weather condition independent and its DHA content which reach up to $48.95 \%$ of its total fat (Ren et al., 2010). This paper will discuss the potential of heterotrophic microalgae (Schizochytrium sp.) as a source of DHA fatty acids.

Recently, one of food supplement industry, Martek, produced omega-3 oil from a different strain of Schizochytrium sp., named Algal Oil which containing approximately $37 \%$ of DHA and $16 \%$ of EPA (w/w). Algal Oil, as a source of DHA and EPA is intended for food ingredient use and dietary supplement (Fedorova et al., 2011a). A number of studies including sub chronic feeding to rodents (Hammond et al., 2001) and non-rodents (Abril et al., 2003), developmental toxicity in rodent and non rodent species (Hammond et al., 2001b), reproduction (Hammond et al., 2001c), and in vitro mutagenicity and genotoxicity (Hammond et al., 2002) confirmed the safety of DHA-rich dried Schizochytrium sp. Recently, DHA algal oil derived from Schizochytrium sp. is generally recognize as safe (GRAS) and available for food use and for dietary supplements (FDA, 2004).

\section{DHA AND BENEFITS}

DHA (Docosahexaenoic acids) is a type of polyunsaturated fatty acids that has chemical structure of C22: $6 n-3$, which is also called as derived omega 3 fatty acids. This fatty acids become important since it was part of essential fatty acids that humans must ingeste because the body requires them for good health but cannot synthesize them. One rich source of DHA is fish oil. The high amount of DHA in fish oil is originated from photosynthetic and heterotrophic microalgae consumed by the fish (Anon., 2009). Currently, DHA is also commercially manufactured from microalgae i.e. Crypthecodinium cohnii and other microalgae from the genus of Schizochytrium.

As shown in Fig. 1, the chemical structure of DHA consist of 22 carbon atoms and 6 double bonds is the longest and the most unsaturated, and therefore perhaps the most influential. Among the member of the omega-3 group of polyunsaturated fatty acids (PUFA), DHA is the longest and the most unsaturated, therefore perhaps DHA is the most influential PUFA (Stillwell et al., 2005). DHA has a tremendous benefit to the human body, especially as the prevention of several diseases such as cancer (Carrol, 1991; Zerouga et al.,1996). DHA is compiler of phospholipids membrane in the human brain and retina. Therefore, pregnant women and infants need to have sufficient DHA intake, especially when pregnancy reaches the age of third trimester in which the average stage development of the brain and retina is the fastest. Infant could fulfill DHA diet by breast milk; however the breast milk is influenced by the mother's diet (Brenna et al., 2007). According to Hoffman et al. (2009) fortification of milk with DHA $0.15-0.36 \%$ from the total fatty acids in the milk improves nutritional quality of infant milk.

\section{TAXONOMY AND MORPHOLOGY OF Schizochytrium}

Schizochytrium is a heterotrophic microalgae belongs to the family of Thraustochytriacaea (Luying et al., 2008). Schizochytrium is a spherical unicellular microorganism. This microorganism has been favored for study as it is much easier to cultivate than other (Wu et al., 2005). According to Yokoyama et al. (2007), morphological characteristics of Schizochytrium under the microscope would show a ectoplasmic nets, a formation of zoospores, aplanospores, and amoeboid cells, and the size between 10-20 $\mu \mathrm{m}$. The taxonomy detail of Schizochytrium is as follows:

$\begin{array}{ll}\text { Kingdom } & \text { : Chromista (Stramenopilia) } \\ \text { Phylum } & \text { : Heterokonta } \\ \text { Class } & : \text { Thraustochytridae } \\ \text { Order } & \text { : Thraustochytriales } \\ \text { Family } & : \text { Thraustochytriaceae } \\ \text { Genus } & \text { : Schizochytrium } \\ \text { Species } & \text { : Schizochytrium } \mathrm{sp} .\end{array}$

(Source: Leipe et al., 1994)

Schizochytrium produces biflagellate zoospore and the mature cells divided by repeated binary division to form diads, tetrads and clusters (Fig. 2). Each Schizochytrium cell could develop into a sporangium that produces several zoospores (Kamlangdee \& Fan, 2003).

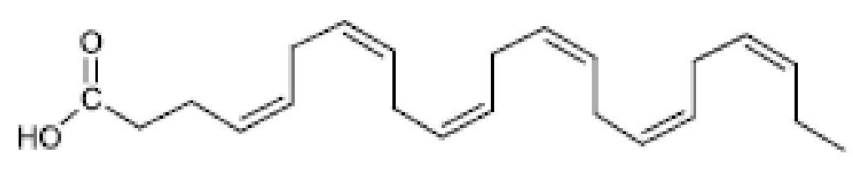

Figure 1. Structure of Docosahexaenoic acid /DHA, 22:6 $6^{\AA 4}, 7,10,13,16,19$ (Source: Stillwell et al., 2005). 

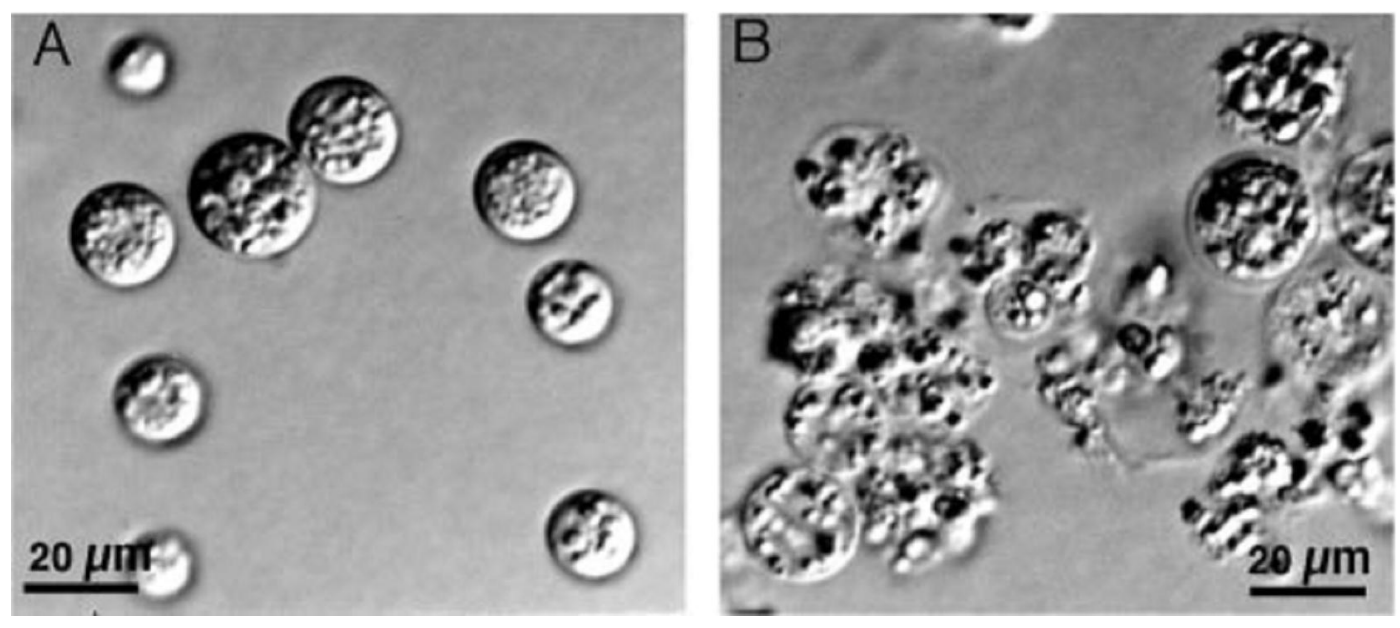

Figure 2. Morfology of Schizochytrium cell (Source: Takao et al., 2005).

\section{ISOLATION OF Schizochytrium}

According to Yang et al. (2010) Scizochytrium could be isolated from macroalgae, fallen leaves of mangrove trees and also mud from mangrove ecosystem. Schizochytrium grows in mangrove and coastal ecosystem. Several studies showed that Schizochytrium is symbiosis with mud degrading bacteria, so that these microalgae also could be isolated from soil or mud around mangroves.

Isolation techniques of Schizochytrium can be initiated by taking samples from those places. The samples were stored in sterile plastic bags and sent to the laboratory within 1 day for algal cell isolation. Microalgal cells attached to samples were washed down using sterile seawater, passed through a 60$\mu \mathrm{m}$. plankton net to remove zooplankton, then collected using a $10-\mu \mathrm{m}$ plankton net. The cells were rinsed several times over a filter using sterile seawater to remove as many bacteria as possible, then transferred by loop, and streaked onto agar plates. The $0.8 \%$ agar medium was prepared using full strength seawater, containing $1 \mathrm{~g} / \mathrm{L}$ peptone, $2 \mathrm{~g} / \mathrm{L}$ yeast extract, $4 \mathrm{~g} / \mathrm{L}$ glucose, and antibiotics including ampicillin (sodium form), streptomycin sulfate, and kanamycin sulfate ( $100 \mathrm{mg} / \mathrm{L}$ each). After inoculation, the plates were wrapped then stored at $26^{\circ} \mathrm{C}$ for $2-5$ days. Single colonies composed of spherical of a typical cell were picked and carefully transferred to a new plate. After becoming established, these algal strains were identified according to their 18S rRNA gene sequences.

Rangkumar (1992) explained different method of isolation of Schizochytrium. Samples were taken from decaying leaves of the mangrove, and were suspended in sterile seawater and baited by piece of pine pollen and then shaken for 2-3 days. Then the leavessuspension was then streaked on agar plates, and incubated for 4-5 days. Single colony grown in the agar then was inoculated in to fresh agar plate. Inoculation was done repeatedly until strains which have characteristics of Schizochytrium has been obtained.

For obtaining DNA sequences of $18 S$ rRNA gene from one strain, a single colony of the strain grown on an agar plate was carefully transferred to a $50 \mathrm{~mL}$ tube with $10 \mathrm{~mL}$ liquid medium containing $1 \mathrm{~g} / \mathrm{L}$ peptone, $2 \mathrm{~g} / \mathrm{L}$ yeast extract, and $4 \mathrm{~g} / \mathrm{L}$ glucose prepared with seawater. The culture was then cultivated at $26^{\circ} \mathrm{C}$ for 1 week with continuous shaking (150 rpm). The algal cells were collected by centrifugation (3.000 $\mathrm{rpm}$ for $5 \mathrm{~min}$ ), rinsed with $5 \mathrm{~mL}$ deionized water, and lyophilized before DNA sequencing (Yang et al., 2010). The resulting 18S rRNA gene sequences were then aligned and compared to the nucleotide sequences of some known microorganisms in GenBank database of the National Center for Biotechnology Information by using Basic Local Alignment Search Tool (BLAST) (Tamura et al., 2007).

The other method to compared to the nucleotide sequences was using multiple alignment program CLUSTAL W to construct a neighbor-jointing (NJ) tree. The bootstrap values were obtained from 1,000 replications of $\mathrm{NJ}$ analyses (Kuo et al., 2005; Burja et al., 2006).

\section{PRODUCTION OF Schizochytrium}

Cultivation of pure culture was conducted in liquid medium to yield Schizochytrium biomass for the extraction of fatty acid content (DHA). Many factors may effect this process such as medium composition, salinity, acidity and temperature. Many research have been conducted to determine the type of carbon and nitrogen that important for the Schizochytrium growth 
Table 1. Effect of carbon sources on biomass, lipid and DHA production

Source: Wu et al. (2005).

Table 2. Effect of nitrogen sources on biomass, lipid, and DHA production

Source: Wu et al. (2005).

and the production of its polyunsaturated fatty acids, especially DHA. According to Wu et al. (2005), type of carbon sources which could be used to grow Schizochytrium were glucose, fructose, lactose, maltose and sucrose. While the nitrogen sources needed to grow Schizochytrium was including yeast extract, peptone, tryptone, urea, monosodium glutamate, sodium nitrate, ammonium chloride. Each medium has different effects on the biomass and DHA production as shown in Table1 and 2.

Meanwhile according to Yokochi et al. (1998), glycerol and monosaccharide (glucose and fructose) could be used to grow Schizochytrium cell (Table 3).

In addition to type of media, initial degree of acidity $(\mathrm{pH})$ also affects on Schizochytrium growth. The initial
$\mathrm{pH}$ value of medium affects cell membrane functions, the uptake of nutrients and product biosynthesis (Kim et al., 2005). Therefore, the $\mathrm{pH}$ of medium influences to the cell growth and metabolites obtained. Maximum biomass $(14.99 \mathrm{~g} / \mathrm{L})$ could be obtained in medium $\mathrm{pH}$ 4.0 whereas maximum DHA $(77 \mathrm{~g} / \mathrm{L})$ was obtained at pH 7.0 (Luying et al., 2008).

Schizochytrium is microalgae that lives in mangrove environment, therefore to obtain the optimum culture conditions, salinity conditions in culture media must be adapted to its natural environment. Salinity affects the growth of the microorganism by controlling the cytoplasmic ion gradient and the activity of enzymes involved in cell wall expansion (Ho \& Chou, 2001). Schizochytrium is high tolerance to salinity and could 
Table 3. Fatty acid composition of Schizochytrium grown on various medium sources

Source: Yokochi et al. (1998).

grow over a wide range of salinity 5-35 ppt (Kamlangdee \& Fan, 2003). Moreover Thraustochytrium aureum and Schizochytrium aggregatum could grow even with salinity as low as 1 ppt, but no growth was observed in a medium prepared from distilled water because of absence of major ions of $\mathrm{Na}, \mathrm{Ca}, \mathrm{K}$ and $\mathrm{Mg}$ which are essential for the growth of microalgae (Bahnweg, 1979). Influence of salinity to the biomass and DHA production is showed in Fig. 4.

Temperature is an important factor for the growth of microorganism includes Schizochytrium. However, Nakahara et al. (1996) found that $28^{\circ} \mathrm{C}$ was the optimal temperature for DHA production from Schizochytrium limacinum. Meanwhile, Luying et al. (2008) explained that Schizochytrium limacinum could grow in temperatures ranging from 16 to $37^{\circ} \mathrm{C}$, while the optimum temperature of DHA production was obtained at $23^{\circ} \mathrm{C}$.

Schizochytrium is expected to be one of alternative DHA sources. Several researchers showed that this microorganism could produce higher DHA. In addition to that, Schizachytrium is irrespective to the weather condition resulting in easier propagation.

Kamlangdee \& Fan (2003) isolated 4 strains of Schizochytrium ( $\mathrm{N}-1, \mathrm{~N}-2, \mathrm{~N}-5$, and $\mathrm{N}-9)$ from fallen, senescent leaves of mangrove tree. These strains were cultivated in glucose yeast extract medium containing

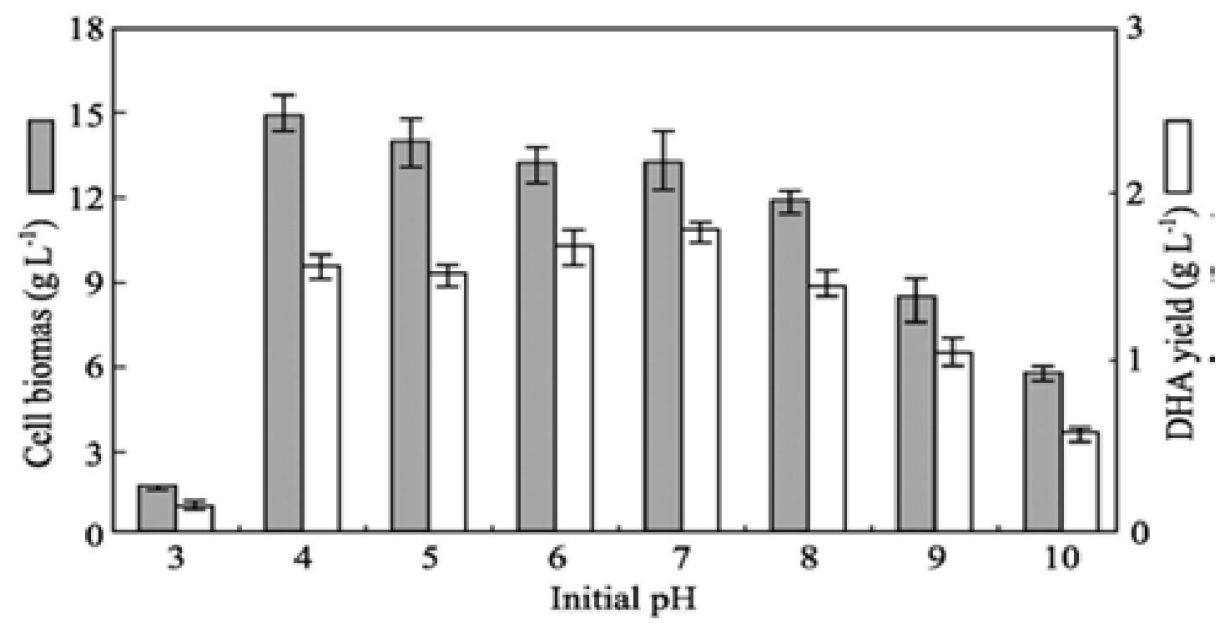

Figure 3. Effects of initial pH on growth of Schizochytrium and DHA production (Source:Luying et al., 2008). 


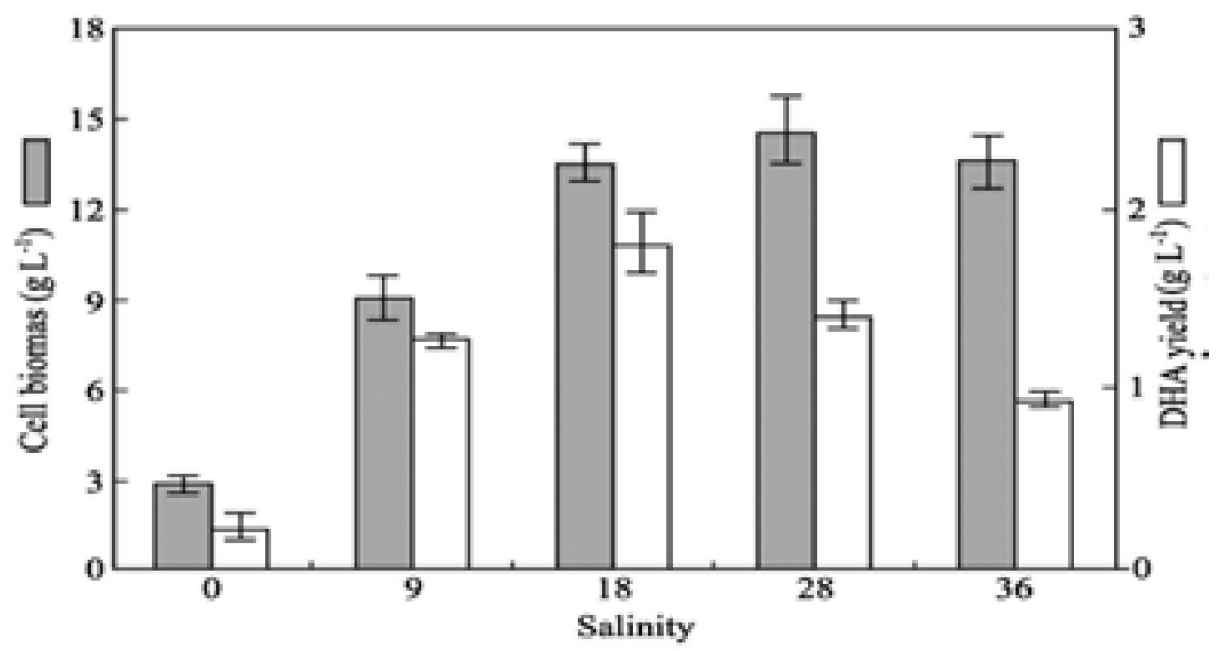

Figure 4. Effects of salinity on growth of Schizochytrium and DHA production (Source: Luying et al., 2008).

$60 \mathrm{~g}$ of glucose, $10 \mathrm{~g}$ of yeast extract and $1 \mathrm{~L}$ of $15 \%$ artificial seawater, initial pH 6.0, with shaking for $52 \mathrm{~h}$ at $25^{\circ} \mathrm{C}$. Biomass of 5 isolates ranged from 10.8 to $13.2 \mathrm{~g} / \mathrm{L}$. The contents of DHA in biomass varied from 157.9-203.6 mg/g of dried-biomass. The result showed that Schizochytrium produced higher DHA level than other bacteria.

Yano et al. (1994) found that five bacterial strains (Vibrio sp.) from the intestine of deep-sea fish produced DHA, and one of them produced $0.8 \mathrm{mg} / \mathrm{L}$ DHA within 6 day. Meanwhile, Bajpai et al. (1991) reported his research about the production of $\mathrm{DHA}$ from Thraustochytrids. The cell productivity of $3.8 \mathrm{~g} / \mathrm{L}$ and DHA productivity of $270 \mathrm{mg} / \mathrm{L}$ for 6 days were obtained on glucose and glutamate. Later, they obtained DHA productivity of $510 \mathrm{mg} / \mathrm{L}$ for 40 hours on soluble starch as carbon source. Furthermore Nakahara et al. (1996) succesfully produced DHA and DPA (Docosapentaenoic) from Schizochytrium cell isolated from the coral reef area of the Yap Islands Japan. Cultivation was conducted in a medium that containing $60 \mathrm{~g}$ glucose, $0.7 \mathrm{~g}$ corn steep liquor, $2 \mathrm{~g}$ $\left(\mathrm{NH}_{4}\right)_{2} \mathrm{SO}_{4}, 3 \mathrm{~g} \mathrm{KH}_{2} \mathrm{PO}_{4}$ in $1 \mathrm{~L}$ of a half salt concentration of artificial sea water at temperature $28^{\circ} \mathrm{C}$. These productivities were equivalent to $9.0 \mathrm{~g} / \mathrm{L}$ dry cells, $2.0 \mathrm{~g} / \mathrm{L}$ DHA and $0.44 \mathrm{~g} / \mathrm{L}$ DPA per day.

Cultivation techniques to increase the biomass of Schizochytrium have been carried out by increasing the concentrations of carbon and nitrogen in the growth medium, or by modifying the culture system. Ganuza et al. (2008) conducted research on the optimization of cell growth of Schizochytrium sp. by employing $\mathrm{pH}$-auxstat system ( $\mathrm{pH}$-auxostat fermentation), and cultivation medium containing glucosa $(150 \mathrm{~g} / \mathrm{L})$ and ammonia $(2.4 \mathrm{~g} / \mathrm{L})$. pH-auxostat fermentation was initiated in which $\mathrm{NH}_{4} \mathrm{OH}$ was added to control the $\mathrm{pH}$
(7). The ammonia concentration within the fermenter was maintained between $300 \mathrm{mg} / \mathrm{L}$ and $400 \mathrm{mg} / \mathrm{L}$ by this strategy. Thus, Schizochytrium sp. could be grown under non-nitrogen limiting conditions to a high biomass density $(60 \mathrm{~g} / \mathrm{L})$ in 2 days. In this period, it was obtained biomass Schizochytrium cell 60 (g/L) which contains fatty acids $25 \%(\mathrm{w} / \mathrm{w})$ and $\mathrm{DHA}$ reaching $40 \%$ of total fatty acids.

Furthermore, Ren et al. (2010) have developed the production technique of DHA from Schizochytrium in $1,500 \mathrm{~L}$ bioreactor. Cultivation was conducted stepwise. The single colony in agar medium was inoculated into a $250-\mathrm{mL}$ flask with $50 \mathrm{~mL}$ medium and cultivated for $24 \mathrm{~h}$, After three generations of cultivation, the preculture was inoculated into a 150-L seed fermentor with an inoculums size of $1 \%(\mathrm{v} / \mathrm{v})$ and cultivated for $24 \mathrm{~h}$. The seed culture $(10 \%, \mathrm{v} / \mathrm{v})$ was then transferred to a $1500-\mathrm{L}$ fermentor with a working volume of $1,000 \mathrm{~L}$ for $96 \mathrm{~h}$. Biomass were achieved $(71 \mathrm{~g} / \mathrm{L})$, and contained high lipid content $(35.75 \mathrm{~g} / \mathrm{L})$, and high DHA percentage $(48.95 \%)$.

Compared with other photoautotroph microorganism, Schizochytrium cell produced higher DHA (Table 4).

\section{POTENTIAL UTILIZATION}

Schizochytrium is underdeveloped in Indonesia. Up to date, only 7 species were found from several mangrove areas in Indonesia (Basuki, 2011); this is likely caused by the lack of information and research about this microalgae. Many factors such as natural environment and medium growth may affects the production of Schizochytrium.

Indonesia has a very large mangrove areas, which is a tremendously potential as a source of isolate local 
Table 4. Profile of fatty acid produced by various microorganisms

Source: Anon., 2002.

Table 5. Result of chemical and physical test of Schizochytrium oil

\begin{tabular}{|c|c|c|}
\hline Chemical Test & Specification & Test Method \\
\hline Acid value & $\leq 0.5 \mathrm{mg} \mathrm{KOH} / \mathrm{g}$ & $\begin{array}{l}\text { AOCS Method Cd } \\
\text { 3d } 63\end{array}$ \\
\hline Peroxide Value & $\leq 5.0 \mathrm{meq} / \mathrm{kg}$ oil & $\begin{array}{l}\text { AOCS Method Cd } \\
8-53\end{array}$ \\
\hline $\begin{array}{l}\text { Moisture and } \\
\text { volatiles }\end{array}$ & $\leq 0.05 \%$ & $\begin{array}{l}\text { AOCS Method Ca } \\
2 \mathrm{~d}-25\end{array}$ \\
\hline Unsaponifiables & $\leq 4.5 \%$ & $\begin{array}{l}\text { AOCS Method Ca } \\
2 \mathrm{~d}-25\end{array}$ \\
\hline Trans-fatty acids & $\leq 2 \%$ & $\begin{array}{l}\text { AOCS Method Ca } \\
6 b-53\end{array}$ \\
\hline DHA & $\geq 32,0 \%$ & $\begin{array}{l}\text { AOCS Method Cd } \\
14-61\end{array}$ \\
\hline Hexane & $\leq 10 \mathrm{mg} / \mathrm{kg}$ & $\begin{array}{l}\text { AOCS Method Ca } \\
3 \mathrm{~b}-87\end{array}$ \\
\hline
\end{tabular}

Source: Baldwin, 1997.

strains of Schizochytrium. Growth media of Schizochytrium are easy to find. Morever, sugar cane molasses which is very abundance in Indonesia can be used to substitute the glucose in the Schizochytrium growth media.
The fact that the alga is capable to utilize glycerol as a carbon source causes the exploration leads to the feasibility of using crude glycerol from biodiesel for growing Schizochytrium. Currently, the market is flooded with an abundance of crude glycerol from 
Table 6. Utilization of Schizochytrium oil in food products

Source: Commission Decisions 2003/427/EC and 2009/778/EC in Howlett (2011).

biodiesel, the use of glycerol as carbon sources to produce PUFA algae provide an alternative utilization of glycerol while economically helping the growth of the biodiesel industry in Indonesia (Basuki, 2011).

Changes in utilization trend of unsaturated fatty acids especially DHA resources in recent years leads to marine microbial as one alternative sources of DHA. The easy, sustainable continuously technology to produce yield high biomass of Schizochytrium has been developed in several industries. Schizochytrium cell $(10-20 \mu \mathrm{m})$ aggregates each other, making it easier in the harvest and filtration process. Schizochytrium biomass could be further used directly as food for shrimp larvae, and the extracted fatty acid can be used as food fortification. Fatty acid extraction from Schizochytrium can be done using organic solvents (hexane). Prior extraction, cell of Schizochytrium must be dried to obtain dried Schizochytrium with 10-15\% moisture content. Then the dried Schizochytrium was milled into smaller size. The mixture of crude oil and organic solvent chilled and then filtered to remove solids. Addition of acid or base was conducted to remove the organic solvent which mixed in oil. The crude oil obtained was then centrifuged to remove the remnants solid that remain. The oil chilled again. If it is intended to be used in a long time, antioxidant should be added into the oil (Anon., 2002; Baldwin, 1997). The chemical test result of Schizochytrium oil can be seen at Table 5 .

Various type of oils from Schizochytrium can be added to foods to increase the content of DHA. Some food product have been fortified using Schizochytrium's oil (Table 6).

\section{CONCLUSION}

Consumers around the world are moving toward functional foods as a way to prevent and to fight diseases, to increase their energy and wellness, and to help them live longer, healthier, more productive lives. They are beginning to search for not only low-fat and low-sugar products, but also for foods considered as natural or with ingredients taken from natural sources as opposed to synthetically produced ingredients. With that in mind, food scientist's found microalgae as a potential source for functional food and bioactive ingredients. In the last few decades microalgae have been produced and marketed as nutraceuticals and food supplements. Genera Schizochytrium, have become popular microalgal as sources of protein-rich biomass and compounds, especially carotenoids, pigments, antioxidant extracts, and essential fatty acids. The potential of heterotrophic microalgae as a source of omega 3 , especially DHA have not been yet widely utilized. The ease of production process, heterotrophic high characteristic level of biomass and DHA produced by Schizochytrium make them more advantages compared to other types of photoautotroph microalgae. The extract oil from Schizochytrium also can be utilized to increase the DHA content in some food products.

\section{REFERENCES}

Abril, R., Garret, J., Zeller, S.G., Sander, W.J., and Mast, R.W. 2003. Safety assessment of DHA-rich microalgae from Schizochytrium sp. Part V. Target animal safety toxicity study in growing swine. Regul. Toxicol. Pharm. 37: 73-82.

Anonymous. 2002. Final assessment report (inquiry section 17) application A 428 DHA-rich dried marine micro algae (schizochytrium sp.) and DHA-rich oil derived from schizochytrium sp. as novel food ingredients. Australia New Zealand Food Authority. $70 \mathrm{pp}$. 
Anonymous. 2009. Docoxahexaenoic acids. Monograph Alternative medicine review. 14 (4): 391-399.

Apt, K.E. and Behrens, P.W.1999. Commercial developments in microalgal biotechnology. $J$. Phycology. 35: 215-226.

Bahnweg, G. 1979. Studies on the physiology of Thraustochytriales I. Growth requirements and nitrogen nutrition of Thraustochytrium spp., Schizochytrium sp., Japonochytrium sp., Ulkenia spp. and Labyrinthuloides spp. Veroff. Inst. Meeresforsch. Bremerh. 17: 245-268.

Bajpai, P.K., Bajpai, P., and Ward, O.P. 1991. Optimization of production of docosahexaenoic acid (DHA) by Thrauatochytrium aureum ATCC 34304. Journal American Oil Chemical Society. 68: 509.

Baldwin, N. 1997. Application for the approval of DHArich oil. OmegaTech $\mathrm{GmbH} .10 \mathrm{pp}$.

Barclay, W.R., Meager, K.M., and Abril, J.R. 1994. Heterotrophic production of long chain omega-3 fatty acids utilizing algae and algae-like microorganisms. J. Applied Phycology. 6: 123-129.

Basuki, W. 2011. Pengembangan teknologi biorefinery untuk produksi Poly Unsaturated Fatty Acid (PUFA) sebagai ingredient Fungsional menggunakan mikroalga Schizochytrium sp. Proposal insentif peningkatan kemampuan peneliti dan perekayasa. Kementerian Negara Riset dan Teknologi. 8 pp.

Brenna, J.T., Varamini, B., and Jensen, R.G. 2007. Docosahexaenoic and arachidonic acid concentration in human breast milk wordwide. $\mathrm{Am}$. J. Cli. Nut. 85: 1457-1464.

Burja, A.M., Radianingtyas, H., Windust, A., and Barrow, C.J. 2006. Isolation and characterization of polyunsaturated fatty acid producing Thraustochytrium species: screening of strains and optimization of omega-3 production. Appl. Microbiol. Biotechnol. 72: 1161-1169.

Commission Decisions. 2009. Commission Decisions 2003/427/EC dan 2009/778/EC dalam Howlett, J. 2011. DHA-rich algal oil from Schizochytrium sp.ONC-T18. Ocean Nutrition Canada Limited. p. 174.

Carroll, K.K.1991. Dietary fats and cancer. Am. J. Clin.Nutr. 53: 1064S-1067S.

De Swaaf, M.E., Sijtsma, L., and Pronk, J.T. 2003. Highcell-density fed-batch cultivation of the docosahexaenoic acid producing marine alga Crypthecodinium cohnii. Biotechnol Bioeng. 81: 666672.

Food and Drug Administration, Department of Health and Human Services, 2004. Substances affirmed as generally recognized as safe: Algal oil (Schizochytrium sp.). GRN no.137

Fedorova, D.I., Marone, P.A., Bailey, H.E., and Ryan, A.S. 2011. Safety evaluation of algal oil from Schizochytrium sp. J. Food and Chemical Toxicol. 49: 70-77.

Hammond, B.G., Mayhew, D.A., Naylor, M.W., Ruecker, F.A., Mast, R.W., and Sander, W.J. 2001a. Safety assessment of DHA-rich microalgae from Schizochytrium sp.Part I. Subchronic rat feeding study. Regul. Toxicol. Pharm. 33: 192-204.
Hammond, B.G., Mayhew, D.A., Holson, J.F., Nemac, M.D., Mast, R.W., and Sander, W.J. 2001b. Safety assessment of DHA-rich microalgae from Schizochytrium sp.Part II. Developmental toxicology evaluation in rats and rabbits. Regul. Toxicol. Pharm. 33: 205-217.

Hammond, B.G., Mayhew, D.A., Robinson, K., Mast, R.W. and Sander, W.J. 2001c. Safety assessment of DHArich microalgae from Schizochytrium sp. Part III. Single generation rat reproduction study. Regul. Toxicol. Pharm. 33: 356-362.

Hammond, B.G., Mayhew, D.A., Kier, L.D., Mast, R.W., and Sander, W.J. 2002. Safety assessment of DHArich microalgae from Schizochytrium sp. Part IV. Mutagenicity studies. Regul. Toxicol. Pharmacol. 35: 255-265.

Ganuza, E., Anderson, A.J., and Ratledge, C. 2008. Highcell-density cultivation of Schizochytrium $s p$. in an ammonium $/ \mathrm{pH}$-auxostat fed-batch system. J. Biotechnol. Lett. 30: 1559-1564.

Howlett, J. 2011. DHA-rich algal oil from Schizochytrium sp.ONC-T18. Ocean Nutrition Canada Limited. p. 174.

Ho, W.I. and Chou, C.C. 2001. Effects of carbon and nitrogen sources, sodium chloride and culture conditions on cytotoxin production by Salmonella choleraesuis. 67: 81-88.

Hoffman, D.R., Boettcher, J.A., and Diersen-Schade, D.A. 2009. Toward optimizing vision and cognition in term infants by dietary docosahexaenoic acid and arachidonic acid supplementation: a review of randomized controlled trials. Prostaglandins Leukot. Essent. Fatty Acids. 81: 151-158.

Kamlangdee, N. and Fan, K.W. 2003. Polyunsaturated fatty acids production by Schizochytrium sp. isolated from mangrove. J. Sci.Tech. 25: 643-650.

Kim, H.O., Lim, J.M., Joo,J.H., Kim, S.W., and Hwang, H.J. 2005. Optimization of submerged culture condition for the production of mycelial biomassa and exopolysaccharides by Agrocybe cylindracea. Biores Technol. 96: 1175-1182.

Kuo, H.C., Su, Y.L., Yang, H.L., and Chen, T.Y. 2005. Identification of Chinese medicinal fungus Cordyceps sinensis by PCR-single-stranded conformation polymorphism and phylogenetic relationship. J. Agric. Food Chem. 53: 3963-3968.

Lewis, T.E., Nichols, P.D., and McMeekin, T.A. 1999. The biotechnological potential of thraustochytrids. J. Marine Biotechnol. 1: 580-587.

Leipe, D.D., Wainright, P.O., and Gunderson, J.H. 1994. The stramenopiles from a molecular perspective: 16S-like rRNA sequences from Labyrinthuloides minuta and Cafeteria roenbergensis. Phycologia. 33 (5): 369-377.

Luying, Z., Xuecheng, Z., Xueying, R., and Qinghua,Z. 2008. Effects of culture conditions on growth and docosahexaenoic acid production from Schizochytrium limacinum. J. Ocean Univ. Chin .7 (1): 83-88.

Nakahara, T., Yokochi, T., Higashihara, T., Tanaka, S., Yaguchi, T., and Honda, D.1996. Production of docosahexaenoic and docosapentaenoic acids by 
Schizochytrium sp. isolated from Yap Islands. J. American Oil Chemical Society. 73: 1421-1426.

Nettleton, J.A. 1995. Omega-3 fatty acids and health. Chapman \& Hall. New York.

Rangkumar, S. 1992. Thraustochytrid marine protists: production of PUFAs and other emerging technologies. J. Marine Biotechnol. 10: 631-640.

Ren, L.J., Ji, X.J., Huang, H., Qu, L., Feng, Y., Tong, Q.Q., and Ouyang, P.K. 2010. Development of a stepwise aeration control strategy for efficient docosahexaenoic acid production by Schizochytrium sp. J. Appl. Microbiol. Biotechnol. 87: 1649-1656.

Spolaore, P., Joannis, C.C., Duran, E., and Isambert, A 2006. Commercial applications of microalgae. J. Bioscience Bioengineer. 101: 87-96.

Stillwell, W., Shaikh, S.R., and Zerouga, M. 2005. Docosahexaenoic acid affects cell signalling by altering lipid rafts. Reprod. Nutr. Dev. 45: 559-579.

Tamura, K., Dudley, J., Nei, M., and Kumar, S. 2007. MEGA4: molecular evolutionary genetics analysis (MEGA) software version 4.0. Molecular Biology Evolution. 24: 1596-1599.

Takao, Y., Nagasaki,K., Mise, K., Okuno, T., and Honda, D. 2005. Isolation and Characterization of a Novel Single-Stranded RNA Virus Infectious to a Marine Fungoid Protist, Schizochytrium sp. (Thraustochytriaceae, Labyrinthulea). J. Appl. and Environmental Microbiology. 4516-4522.

Ward, O.P. and Singh, A. 2005. Omega-3/6 fatty acids: alternative sources of production. J. Process Biochem. 40: 3627-3652.
Wu, S.T. and Lin, L.P. 2003. Application of response surface methodology to optimize docosahexaenoic acid production by Schizochytrium sp. S31. J. Food Biochem. 27: 127-139.

Wu, S.T., S.T.Yu., and L.P, Lin. 2005. Effect of culture conditions on docosahexaenoic acid production by Schizochytrium sp. S31. J. Process Biochemistry. 40: 3103-3108.

Yang, H.L., Lu, C.K., Chen, S.F., and Chen, Y.M. 2010. Isolation and characterization of Taiwanese heterotrophic microalgae: screening of strains for docosahexaenoic acid (DHA) production. J. Marine Biotechnology. 12: 173-185.

Yano, Y., Nakayama, A., Saito, H., and Ishihara, K. 1994. Production of Docosahexaenoic Acid by Marine Bacteria Isolated from Deep Sea Fish. Ibid. 29: 527528.

Yokochi, T., Honda, D., Higashihara, T., and Nakahara, T. 1998. Optimization of Docosahexaenoic Acid Production by Schizochytrium limacinum SR21. Appl. Microbiol. Biotechnol. 49: 72-76.

Yokoyama, R., Salleh, B., and Honda, D. 2007. Taxonomic rearrangement of the genus Ulkenia sensu lato based on morphology, chemotaxonomical characteristics, and 18S rRNA gene phylogeny (Thraustochytriaceae, Labyrinthulomycetes): emendation for Ulkenia and erection of Botryochytrium, Parietichytrium, and Sicyoido chytrium gen. nov. Mycoscience. 48: 329-34.

Zerouga, M., Stillwell, W., Stone, J., Powner, A., Dumaual, A.C., and Jenski, L.J.1996. Phospholipid class as a determinant in docosahexaenoic acid's effect on tumor cell viability. Anticancer Res. 16: 2863-2868. 